\title{
Ellipsis
}

2014

\section{What They Say is True: Your Other Senses Do Sharpen When You Only Have Darkness to Look Forward To}

Courtney Hilden

University of New Orleans

Follow this and additional works at: https://scholarworks.uno.edu/ellipsis

Part of the Poetry Commons

\section{Recommended Citation}

Hilden, Courtney (2014) "What They Say is True: Your Other Senses Do Sharpen When You Only Have Darkness to Look Forward To," Ellipsis: Vol. 41 , Article 3.

DOI: https://doi.org/10.46428/ejail.41.03

Available at: https://scholarworks.uno.edu/ellipsis/vol41/iss1/3

This Poetry is brought to you for free and open access by the Department of English and Foreign Languages at ScholarWorks@UNO. It has been accepted for inclusion in Ellipsis by an authorized editor of ScholarWorks@UNO. For more information, please contact scholarworks@uno.edu. 


\section{What They Say is True: Your Other Senses Do Sharpen When You Only Have Darkness to Look Forward To Courtney Hilden}

I picked

out the coffin by smelling inside

each, worried that we were getting

something previously

occupied or a rental. Neither would

do for Mother, so I rejected the one that smelled

of petrol and potato sacs. I sang her favorite

hymns with the enthusiasm I generally save

for sand bagging. I decided

after the divorce I wanted to memorize

your snow crutched steps

that I can hear from my bed when you think

I won't know of your visits. The house feels it too:

her joints snap to attention. If you'd just shuffle

your feet across the carpet, she'd rev you up

for a doorknob shock.

Perhaps you visit me because I come to stare at your

home by holding out my right arm and counting

seven mailboxes. Don't clean up for me; it looks the same

as everything

now. You must notice the white salt

line halfway up my jeans, the soiled

sneakers. The ice underneath itches

for me to slip. Tell me if the night brims

like those cups of coffee that Sharon used

to serve us on our breaks,

but I know better: You're at the strip

mall parking lot, smoking

with the other boys, playing

Focus Tailgate or Camry Bar, 
depending on what shift works close, the perimeter decked out with bullet holes, the crush in your van's fender unhealed.

One night you will circle my lawn and return to your vehicle and find me feeling at the indent. trying to measure my former body like a man evaluating the growing ticks on his mother's kitchen's door frame. It forms in my mind like a child with Play-Doh, squishing into shape. Were any of us ever this small? Yes and no. 